\title{
IMPLEMENTASI METODE BOOTSTRAP DALAM INFERENSI TITIK- TITIK BIPLOT AMMI MODEL AMMI CAMPURAN (MIXED AMMI) (Studi Kasus: Menduga Stabilitas Genotipe Padi)
}

\author{
Ni Putu Ayu Dinita Trisnayanti ${ }^{\S 1}$, I Komang Gde Sukarsa ${ }^{2}$, Ni Luh Putu Suciptawati ${ }^{3}$ \\ ${ }^{1}$ Jurusan Matematika, Fakultas MIPA - Universitas Udayana [Email:ayudinitatrisna99@gmail.com] \\ ${ }^{2}$ Jurusan Matematika, Fakultas MIPA - Universitas Udayana [Email: sukarsakomang@yahoo.com] \\ ${ }^{3}$ Jurusan Matematika, Fakultas MIPA - Universitas Udayana [Email: putusuciptawati@yahoo.co.id] \\ ${ }^{\S}$ Corresponding Author
}

\begin{abstract}
In this research bootstrap methods are used to determine the points inference of biplot figures on the analysis of AMMI. If the environmental factors are assumed to be random factors, then Mixed AMMI is used as a model of analysis. In the analysis of the stabilit, the main components score interaction used are $\mathrm{KUI}_{1}$ and $\mathrm{KUI}_{2}$. The purpose of this study is to determine the Biplot figures based on two scores these are KUI with the greatest diversity of Mixed AMMI models and the points inference by using the bootstrap method. The stable genotypes obtained from biplot $A M M I_{2}$ are $G_{1}, G_{5}$, and $G_{6}$. Based on points inference of each genotype, $G_{1}$ and $G_{5}$ can be regarded as the most stable genotype. This is because the distribution of $G_{1}$ and $G_{5}$ are the closest to the center point $(0,0)$ and both of them have a small radius.
\end{abstract}

Keywords: Bootstrap, AMMI, Mixed AMMI, biplot.

\section{PENDAHULUAN}

Metode bootstrap merupakan metode simulasi berbasiskan data yang dapat digunakan untuk inferensi statistika (Efron, et al [1]). Menurut Novianti, et al [5] sebagai metode yang diperlukan dalam inferensi statistika, metode bootstrap dapat digunakan untuk menduga inferensi titik-titik dari skor komponen utama interaksi.

Skor komponen utama interaksi diperoleh melalui penguraian nilai singular (SVD) matriks sisaan komponen aditif yang merupakan suatu bagian pada analisis Additive Main Effect and Multiplikatif Interaction (AMMI). Analisis AMMI merupakan suatu teknik analisis data yang diterapkan pada percobaan multilokasi untuk mengkaji interaksi genotipe dengan lingkungan (Mattjik, et al [4]).

Pada analisis AMMI melibatkan faktor genotipe dan lingkungan. Jika lingkungan yang dilibatkan dianggap sebagai faktor acak, maka analisis AMMI yang digunakan adalah model

AMMI campuran (Mixed AMMI). Untuk analisis stabilitas, digunakan skor komponen utama interaksi pertama $\left(\mathrm{KUI}_{1}\right)$ dan skor komponen utama interaksi kedua $\left(\mathrm{KUI}_{2}\right)$. Dengan melibatkan dua skor komponen utama interaksi dengan keragaman terbesar pertama dan kedua, kemudian divisualisasikan ke dalam Biplot $\mathrm{AMMI}_{2}$.

Penelitian terkait metode bootstrap dalam model AMMI dilakukan oleh Lavoranti et.al [3] dan penelitian terkait model Mixed AMMI dilakukan oleh Prihartini [6] untuk mengukur tingkat kestabilan genotipe padi di Jawa Barat.

Interaksi Genotipe Lingkungan (IGL) melibatkan faktor genotipe dan lingkungan. Pengujian yang digunakan dalam mengkaji IGL adalah analisis Additive Main Effects Multiplicative Interaction (AMMI).

Menurut Sumertajaya [8], asumsi yang membedakan analisis AMMI terkait model tetap dan model campuran adalah: 
1. Asumsi Model AMMI tetap:

$$
\begin{aligned}
& \sum_{g=1}^{a} \alpha_{g}=0 ; \sum_{\theta=1}^{b} \beta_{e}=0 ; \\
& \sum_{g=1}^{a}(\alpha \beta)_{g e}=\sum_{\theta=1}^{b}(\alpha \beta)_{g e}=0 ; \\
& \varepsilon_{g e r} \sim N\left(0, \sigma_{s}^{2}\right) ;
\end{aligned}
$$

2. Asumsi Model AMMI campuran:

$\sum_{g=1}^{a} \alpha_{g}=0 ; \beta_{e} \sim N\left(0, \sigma_{\beta}^{2}\right)$;

$$
(\alpha \beta)_{g e} \sim N\left(0, \sigma_{\alpha \beta}^{2}\right) ; \varepsilon_{g e r} \sim N\left(0, \sigma_{s}^{2}\right) \text {. }
$$

Model linier percobaan multilokasi dengan model Mixed AMMI secara lengkap dapat dituliskan sebagai:

$$
\begin{aligned}
& Y_{g e r}=\mu+\alpha_{g}+\beta_{e}+ \\
& \sum_{r=1}^{n} \sqrt{\lambda_{r}} \varphi_{g r} \rho_{e r}+\delta_{g e}+ \\
& \varepsilon_{g e r}
\end{aligned}
$$

dengan:

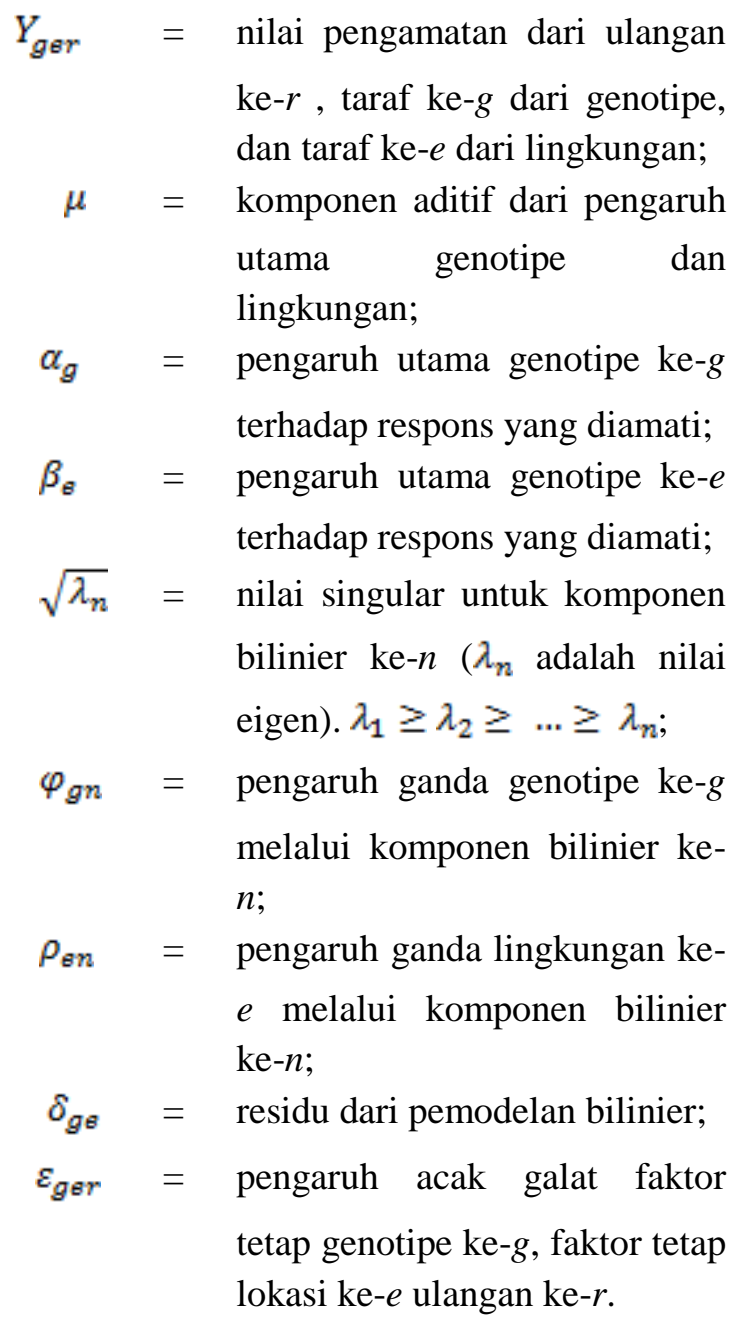

Adanya pengaruh interaksi genotipe dengan lingkungan dapat diketahui melalui penguraian nilai singular untuk matriks interaksi Z. Penguraian nilai untuk matriks pengaruh interaksi $\boldsymbol{Z}$ adalah dengan memodelkan matriks tersebut (Jollife, [2]) sebagai berikut:

$$
\mathbf{Z}=\mathbf{U} \mathbf{L} \mathbf{A}^{\mathbf{T}} \text {. }
$$

matriks $\mathbf{U}$ dan $\mathbf{A}$ merupakan matriks dengan kolom orthonormal, dan matriks $\mathbf{L}$ merupakan matriks diagonal dengan unsur diagonalnya adalah akar kuadrat nilai eigen positif bukan nol. Unsur-unsur diagonal dari matriks $\mathbf{L}$ disebut nilai singular matriks $\mathbf{Z}$.

Pada biplot AMMI kontur ellips yang digunakan diperoleh dari perhitungan jari-jari ellips yang dapat digunakan untuk menentukan titik pusat koordinasi ellips. Persamaan yang digunakan untuk mendapatkan jari-jari ellips (Sa'diyah, et.al [7]) adalah:

$$
r_{i}= \pm \lambda_{i} \sqrt{\left(\frac{2(n-1)}{n(n-p)} F_{p, n-p(\alpha)}\right)}
$$

dengan:

$r_{i}=$ panjang jari-jari; $i=1$ untuk jari-jari panjang; $i=2$ untuk jari-jari pendek;

$n=$ banyaknya pengamatan (genotipe + lingkungan);

$p \quad=\quad$ banyaknya peubah;

$\lambda_{i}=$ nilai singular.

Untuk mempermudah melihat tingkat stabilitas suatu genotipe terhadap lingkungan digunakan indeks stabilitas. Penentuan Indeks stabilitas genotipe ditentukan oleh skor KUI yang dihasilkan oleh model $\mathrm{AMMI}_{2}$, yaitu dengan hanya menggunakan skor $\mathrm{KUI}_{1}$ dan skor $\mathrm{KUI}_{2}$ dari masing-masing genotipe. Indeks stabilitas tersebut didefinisikan (Sa'diyah, et.al [7]):

$$
\text { ISA }=\sqrt{\frac{\lambda_{2}}{\lambda_{2}}\left(\text { skor } K U I_{1}\right)^{2}+\left(\text { skor } K U I_{2}\right)^{2}}
$$

Pada gambaran biplot AMMI, plot antara $\mathrm{KUI}_{1}$ dan $\mathrm{KUI}_{2}$ hanya berupa titik-titik. Sehingga, untuk memberikan keakuratan terkait stabilitas genotipe, maka digunakanlah metode bootstrap untuk inferensi titik-titik amatan. Prosedur metode bootstrap menurut Efron, et al [1] adalah dengan memisalkan sampel acak berukuran $\mathrm{n}$ yaitu $x_{1}, x_{2}, \ldots, x_{n}$ yang diambil 
dari suatu populasi dengan fungsi distribusi kontinu $F$ yang tidak diketahui atau berdistribusi identik dan saling bebas (IID) dan nilai stastistik $\tilde{\theta}$ merupakan estimasi parameter dari $\theta$ berdasarkan data asli.

Menurut Efron, et al [1] langkah pendugaan bootstrap adalah menarik beberapa sample bootstrap yang saling bebas, menghitung penduga dari ulangan bootstrap, menduga galat baku dari $\widehat{\theta}$ menggunakan galat baku empiris dari ulangan bootstrap.

Pada penggunannya, metode bootstrap hanya membutuhkan penggabungan perhitungan iterasi menggunakan komputer (software) untuk mendapatkan penduga parameter karena melibatkan perhitungan yang sangat banyak.

\section{METODE PENELITIAN}

\section{A. Sumber Data}

Penelitian ini bersumber pada data dari Prihartini [6] yang diperoleh dari Balai Penelitian Tanaman Padi Sukamandi, Subang, Jawa Barat. Data menggunakan tujuh genotipe padi, dengan mengambil empat lingkungan penelitian. Pada data ini lingkungan diasumsikan sebagai faktor acak.

\section{B. Teknik Analisis}

Tahapan analisis dalam penelitian ini adalah:

1. Melakukan analisis AMMI dengan model Mixed AMMI

a. Menginterpretasikan data percobaan ke dalam tabel ANOVA.

b. Menguraikan nilai SVD.

2. Menentukan daerah kepercayaan biplot $\mathrm{AMMI}_{2}$.

3. Melakukan Proses Resampling Bootstrap

a. Dari 3 ulangan hasil pengamatan padi untuk setiap genotipe di setiap lingkungan diambil 3 sampel secara acak dengan pengembalian.

b. Data sampel yang diperoleh dari langkah (a) kemudian dianalisis menggunakan analisis AMMI dengan model Mixed AMMI untuk menduga parameter komponen aditif dan matriks interaksi, sehingga diperoleh skor Komponen Utama Interaksi (KUI). Dua skor KUI terbesar yaitu $\mathrm{KUI}_{1}$ dan $\mathrm{KUI}_{2}$ ditentukan untuk setiap genotipe $\left(\theta_{g}^{*}=\left[K U I_{1 g}^{*}, K U I_{2 g}^{*}\right]\right) \quad$ dan lingkungan $\left(\theta_{\theta}^{*}=\left[K U I_{1 \theta}^{*}, K U I_{2 e}^{*}\right]\right)$.

4. Langkah 4(a) dan 4(b) dilakukan proses bootstrap untuk awal yaitu sebanyak $B^{*}=1000$ kali sampai 1000000 kali sehingga diperoleh $\theta_{g l}^{*}$ dan $\theta_{\theta l}^{*}$; $l=1,2, \ldots, B^{*}$.

5. Dari proses resampling yang dilakukan, kemudian ditentukan jarak $r^{*}$ dihitung batas atas $\left(r_{\text {luar }}^{*}\right)$ dan batas bawah $\left(r_{\text {dalam }}^{*}\right)$ dengan selang kepercayaan $\alpha=95 \%$

$$
\begin{aligned}
r_{\text {luar }}^{*}= & \bar{r}^{*}+{ }^{z \alpha} / 2^{\sigma_{r}} \\
& \text { dan } \\
& r_{\text {dalam }}^{*}=\bar{r}^{*}-z \alpha / 2 \sigma_{r}
\end{aligned}
$$

6. Membuat daerah kepercayaan berdasarkan dugaan parameter menurut langkah 5 dimana skor $K U I_{1}^{*}$ dan $K U I_{2}^{*}$ untuk masing-masing genotipe yang nantinya akan diplotkan ke dalam grafik

\section{HASIL DAN PEMBAHASAN}

\section{A. Analisis Ragam Produksi Padi}

Pengujian analisis ragam dilakukan untuk melihat apakah ada pengaruh interaksi genotipe dengan lingkungan. Berikut merupakan hasil analisis ragam (ANOVA) data pengamatan sebelum dilanjutkan dengan analisis AMMI.

Tabel 1. Analisis Ragam Produksi Padi

\begin{tabular}{|c|c|c|c|c|c|}
\hline $\begin{array}{c}\text { Sumber } \\
\text { Keragaman }\end{array}$ & $\mathrm{db}$ & $\mathrm{JK}$ & $\mathrm{KT}$ & $\mathrm{F}_{\text {hit }}$ & $\mathrm{P}_{\text {value }}$ \\
\hline Genotipe & 6 & 10,24 & 1,70 & 30,42 & 0,00 \\
\hline Lingkungan & 3 & 5,08 & 1,69 & 30,22 & 0,00 \\
\hline Interaksi & 18 & 23,21 & 1,29 & 22,97 & 0,00 \\
\hline Galat & 56 & 3,14 & 0,05 & & \\
\hline Total & 84 & 772,4 & & & \\
\hline
\end{tabular}

Hasil ANOVA untuk interaksi produksi hasil padi dari tujuh genotipe pada empat lingkungan di atas menunjukkan bahwa seluruh pengaruh utama (genotipe dan 
lingkungan) dan pengaruh interaksi genotipe dengan lingkungan berpengaruh nyata pada nilai $p$-value 0,0000 .

\section{B. Penguraian Nilai Singular}

Hasil penguraian nilai singular terhadap matriks dengan pengaruh interaksi menghasilkan empat nilai singular tidak nol, yaitu 1,479571 ; 1,272128; 0,7523913; dan 2,862286 × $10^{-8}$. Dari nilai singular tersebut terlihat bahwa banyaknya komponen utama interaksi (KUI) yang dapat dipertimbangkan untuk model Mixed AMMI adalah komponen ke-1 sampai komponen ke-4. Diperoleh pula empat nilai eigen yaitu 2,189129; 1,618309; 0,5660927; dan $8,192681 \times 10^{-16}$.

\section{Analisis Ragam Data Hasil Produksi Padi dengan Mixed AMMI}

Dari penguraian nilai singular dengan memperoleh empat nilai eigen, kemudian dilakukan kembali penghitungan analisis ragam model Mixed AMMI. Analisis ragam model Mixed AMMI ini memperlihatkan skor KUI yang signifikan dan dapat masuk ke dalam model.

Tabel 2. Analisis Ragam Data Hasil Produksi Padi dengan Mixed AMMI

\begin{tabular}{|c|c|c|c|c|c|}
\hline SK & DB & JK & KT & $F_{\text {hitung }}$ & $F_{\text {tabel }}$ \\
\hline Gen & 6 & 10,245 & 1,708 & 1,324 & 2,66 \\
\hline Ling & 3 & 5,089 & 1,696 & 31,407 & 2,78 \\
\hline Interaksi & 18 & 23,213 & 1,290 & 23,88 & 1,86 \\
\hline $\mathrm{KUI}_{1}$ & 8 & 6,567387 & 0,821 & 15,203 & 2,12 \\
\hline $\mathrm{KUI}_{2}$ & 6 & 4,854927 & 0,809 & 14,981 & 2,27 \\
\hline $\mathrm{KUI}_{3}$ & 4 & 1,6982781 & 0,424 & 7,8518 & 2,54 \\
\hline Kelompok & 2 & 0,198 & 0,099 & 1,8333 & \\
\hline Galat & 54 & 2,941 & 0,054 & & \\
\hline Total & 83 & 41,485 & & & \\
\hline
\end{tabular}

\section{Penentuan Banyaknya KUI yang Masuk ke dalam Model}

Penentuan skor KUI yang dapat masuk dalam model dapat dilakukan dengan menghitung nilai kontribusi masing-masing KUI. Kontribusi masing-masing KUI adalah $\mathrm{KUI}_{1}$ sebesar $50.05 \%, \mathrm{KUI}_{2}$ sebesar $37.00 \%$, $\mathrm{KUI}_{3}$ sebesar $12.94 \%$, dan $\mathrm{KUI}_{4}$ sebesar $0.0187 \%$. Berdasarkan analisis ragam model Mixed AMMI dan kontribusi masing-masing KUI, dapat dilihat bahwa KUI yang dapat masuk ke dalam model adalah $\mathrm{KUI}_{1}, \mathrm{KUI}_{2}$, dan $\mathrm{KUI}_{3}$. Ketiga komponen utama tersebut mampu menerangkan keragaman total hasil produksi tanaman padi sebesar $50,05 \%+37,00 \%+$ $12,94 \%=99,99 \%$ yaitu suatu tingkat keragaman yang tinggi. Hal ini berarti daya hasil dapat diterangkan dengan menggunakan Mixed AMMI model $\mathrm{AMMI}_{3}$. Sehingga model $\mathrm{AMMI}_{3}$ untuk pendugaan respon daya hasil dapat dituliskan sebagai berikut:

$$
\hat{Y}_{g E Y}=\mu+\alpha_{g}+\beta_{\theta}+\sum_{\gamma=1}^{a} \sqrt{\lambda_{r}} \varphi_{g r} \rho_{g Y}+\delta_{g E}+\varepsilon_{g E Y}
$$

Untuk penentuan stabilitas genotipe digunakan skor komponen utama interaksi dengan keragaman terbesar pertama $\left(\mathrm{KUI}_{1}\right)$ dan skor komponen utama interaksi dengan keragaman terbesar kedua $\left(\mathrm{KUI}_{2}\right)$. Sehingga, dari dua komponen utama interaksi yang digunakan kontribusi keragaman yang diberikan sudah sangat tinggi yaitu sebesar $50,05 \%+$ $37,00 \%=87,05 \%$. Hal ini sudah lebih dari cukup atau sudah melebihi $50 \%$ untuk dapat menentukan stabilitas genotipe.

\section{E. Daerah Kepercayaan Biplot AMMI}

Pada Biplot $\mathrm{AMMI}_{2}$ dari analisis AMMI dapat digunakan untuk dapat melihat genotipegenotipe stabil pada seluruh lokasi percobaan. Dalam membantu melihat genotipe-genotipe yang stabil digunakan daerah kepercayaan ellips pada biplot dengan titik pusat $(0,0)$ sebagai ukuran dalam menentukan genotipe yang stabil.

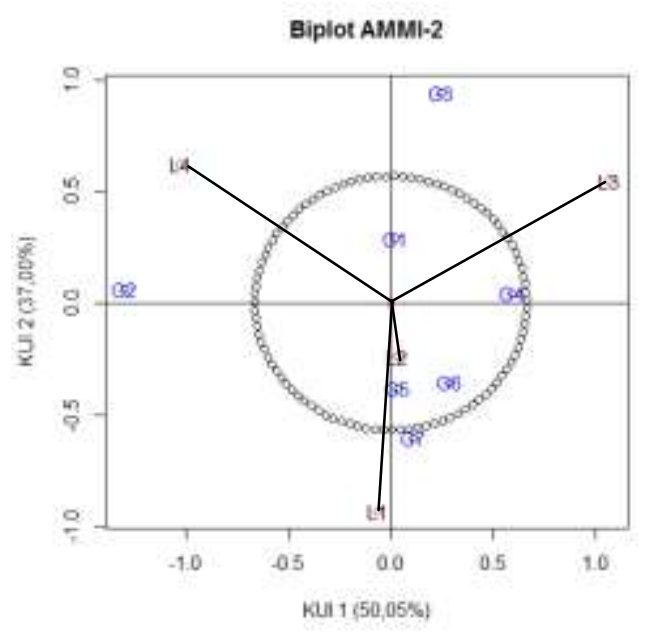

Gambar 1. Biplot $\mathrm{AMMI}_{2}(87,05 \%)$ 
Daerah kepercayaan yang terbentuk pada Biplot $\mathrm{AMMI}_{2}$ mengindikasikan bahwa konturnya berupa circular. Perubahan kontur ini terjadi akibat ragam $\mathrm{KUI}_{1}^{*}$ dan ragam $\mathrm{KUI}_{2}^{*}$ yang diperoleh menghasilkan nilai keragaman yang sama. Pendugaan sebaran titik-titik amatan pada Biplot dilakukan menggunakan metode bootstrap

Konsep kestabilan juga ditunjukkan dari Indeks Stabilitas AMMI (ISA) yang melihat posisi relatif genotipe terhadap titik pusat biplot $\mathrm{AMMI}_{2}$. Hasil perhitungan ISA dapat dilihat pada Tabel 3.

Tabel 3. Indeks Stabilitas AMMI (ISA)

\begin{tabular}{|c|c|c|}
\hline Genotipe & ISA & Peringkat \\
\hline $\mathrm{G}_{1}$ & 0,0955 & $1^{*}$ \\
\hline $\mathrm{G}_{2}$ & 2,334 & 7 \\
\hline $\mathrm{G}_{3}$ & 0,958 & 6 \\
\hline $\mathrm{G}_{4}$ & 0,69 & 5 \\
\hline $\mathrm{G}_{5}$ & 0,3819 & 2 \\
\hline $\mathrm{G}_{6}$ & 0,4892 & 3 \\
\hline $\mathrm{G}_{7}$ & 0,6175 & 4 \\
\hline
\end{tabular}

Hasil ISA diperoleh dengan mengurutkan jari-jari ISA untuk masing-masing genotipe dari genotipe dengan ISA yang terkecil. Genotipe dengan ISA lebih kecil dari nilai $\alpha=0,05$, maka genotipe tersebut lebih dekat dengan titik pusat $(0,0)$.

Berdasarkan hasil Biplot $\mathrm{AMMI}_{2}$, terlihat bahwa genotipe yang berada di dalam area kontur adalah $\mathrm{G}_{1}, \mathrm{G}_{5}$, dan $\mathrm{G}_{6}$. Genotipe $\mathrm{G}_{4}$ berada berbatasan dengan area kontur, sehingga tidak dapat dikatakan berada di dalam kontur dan tidak dapat juga dikatakan berada di luar area kontur. Sedangkan, $\mathrm{G}_{2}, \mathrm{G}_{3}$ dan $\mathrm{G}_{7}$ menyebar di luar area kontur.

Dari gambar Biplot $\mathrm{AMMI}_{2}$ dan berdasarkan ISA dapat diduga bahwa genotipe yang berada di dalam area kontur dan memiliki jarak yang dekat dengan titik pusat $(0,0)$ dapat dikategorikan sebagai genotipe yang stabil untuk seluruh lingkungan percobaan. Genotipegenotipe yang dikategorikan sebagai genotipe stabil bila berdasarkan Biplot $\mathrm{AMMI}_{2}$ adalah
$\mathrm{G}_{1}, \mathrm{G}_{5}$, dan $\mathrm{G}_{6}$. Sedangkan, Genotipe-genotipe yang dikategorikan sebagai genotipe yang tidak stabil adalah $\mathrm{G}_{2}, \mathrm{G}_{3}, \mathrm{G}_{4}$, dan $\mathrm{G}_{7}$.

\section{F. Implementasi Bootstrap dalam Inferensi Titik-titik.}

Pendekatan untuk menentukan inferensi titik-titik dilakukan dengan metode resampling bootstrap. Pada gambaran Biplot $\mathrm{AMMI}_{2}$, plot antara $\mathrm{KUI}_{1}$ dan $\mathrm{KUI}_{2}$ untuk melihat kestabilangenotipe hanya berupa suatu titik dari setiap genotipe dan hanya menyatakan keragaman genotipe tersebut. Melalui pendekatan resampling bootstrap akan diperoleh penampilan plot antara $\mathrm{KUI}_{1}$ dan $\mathrm{KUI}_{2}$ berupa titik-titik dugaan atau titik-titik inferensi dalam menentukan kestabilan genotipe.

Proses resampling dilakukan pada data asli yang memiliki 3 data ulangan dengan mengambil 3 data baru secara acak dengan pengembalian untuk setiap genotipe di setiap lingkungan, sehingga akan terbentuk $3^{3}=27$ kombinasi data yang mungkin terjadi. Pada penelitian ini melibatkan 7 genotipe padi dan 4 lingkungan dengan perlakuan 3 kali ulangan maka akan diperoleh $27^{7 \times 4}$ matriks interaksi.

Proses resampling yang digunakan adalah dengan iterasi sebanyak 1000 kali. Proses resampling yang dilakukan sebanyak 1000 kali bertujuan untuk melihat keakuratan inferensi titik-titik pada setiap amatan. Semakin banyak iterasi yang dilakukan, maka semakin akurat inferensi tititk-titik pada gambaran biplot untuk masing-masing genotipe.

Gambaran inferensi titik-titik amatan untuk setiap genotipe ditampilkan pada gambar 3(a), 3(b), 3(c), 3(d), 3(e), 3(f), 3(g).

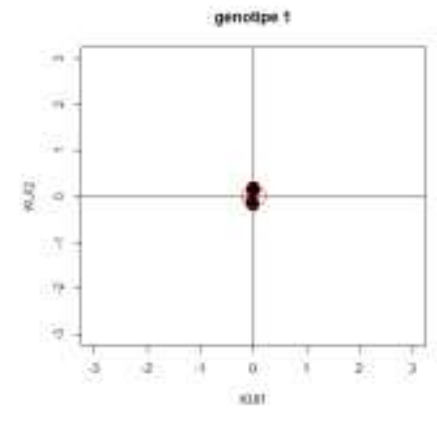

3(a) 


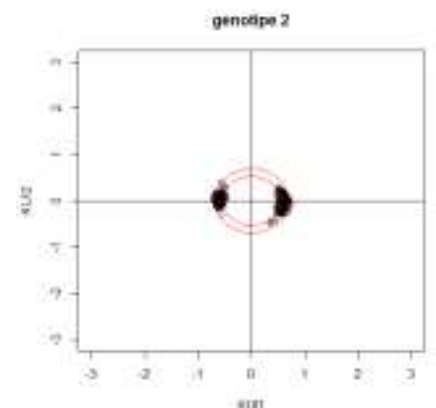

3(b)

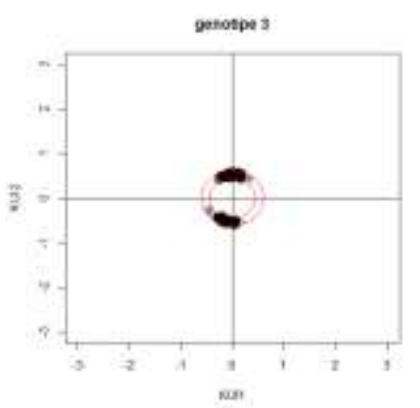

3(c)

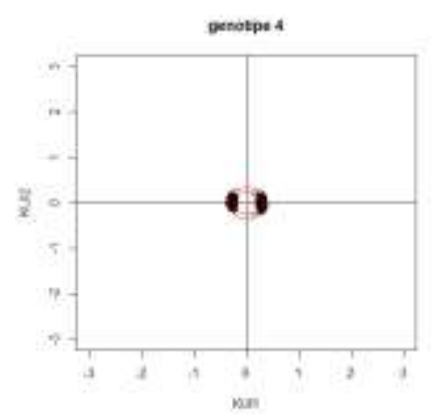

3(d)

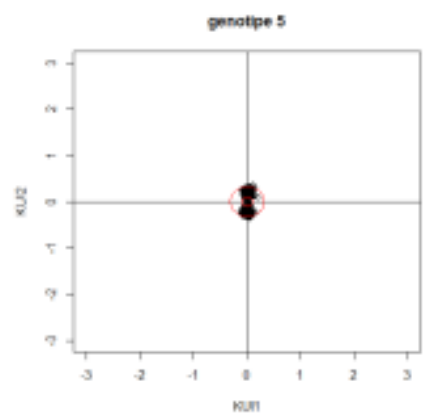

$3(\mathrm{e})$

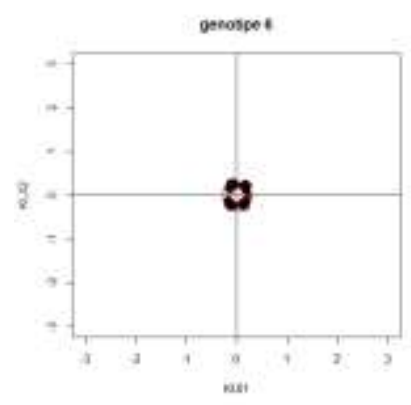

3(f)

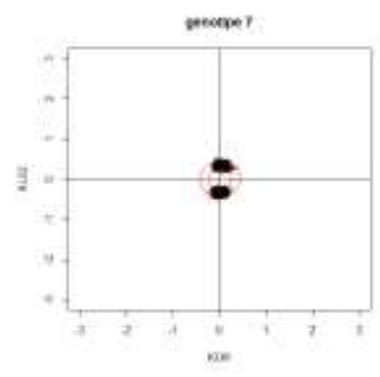

$3(\mathrm{~g})$

Berikut ini jarak sebaran titik-titik inferensi dengan titik pusat $(0,0)$ dengan menghasilkan batas atas $\left(r_{\text {luar }}^{*}\right)$ dan batas bawah $\left(r_{\text {dalam }}^{*}\right)$ sebagai jari-jari lingkaran dari masing-masing genotipe.

Tabel 4. Jari-jari Lingkaran

\begin{tabular}{|c|l|l|l|c|}
\hline \multirow{2}{*}{ Genotipe } & \multirow{2}{*}{ Rataan } & \multirow{2}{*}{$\begin{array}{c}\text { Simpangan } \\
\text { Baku }\end{array}$} & \multicolumn{2}{|c|}{$\begin{array}{c}\text { Jari-jari } \\
\text { lingkaran }\end{array}$} \\
\hline & & & $\begin{array}{c}\text { Batas } \\
\text { atas }\end{array}$ & $\begin{array}{c}\text { Batas } \\
\text { bawah }\end{array}$ \\
\hline $\mathrm{G}_{1}$ & 0,158 & 0,035 & 0,228 & 0,089 \\
\hline $\mathrm{G}_{2}$ & 0,613 & 0,041 & 0,693 & 0,532 \\
\hline $\mathrm{G}_{3}$ & 0,526 & 0,040 & 0,606 & 0,446 \\
\hline $\mathrm{G}_{4}$ & 0,286 & 0,026 & 0,338 & 0,235 \\
\hline $\mathrm{G}_{5}$ & 0,207 & 0,055 & 0,317 & 0,098 \\
\hline $\mathrm{G}_{6}$ & 0,240 & 0,031 & 0,302 & 0,178 \\
\hline $\mathrm{G}_{7}$ & 0,339 & 0,046 & 0,430 & 0,248 \\
\hline
\end{tabular}

Genotipe $\mathrm{G}_{1}$ memiliki daerah kepercayaan batas atas $\left(r_{\text {luar }}^{*}\right)$ dan batas bawah $\left(r_{\text {dalam }}^{*}\right)$ yang mendekati titik pusat $(0,0)$, serta sebaran titik-titik inferensi pada $G_{1}$ mengumpul dan masih berada di dalam kontur. Sehingga, genotipe $G_{1}$ dapat diidentifikasi sebagai genotipe stabil.

Genotipe $G_{2}, G_{3}, G_{4}$, dan $G_{7}$ memiliki daerah kepercayaan batas atas $\left(r_{\text {luar }}^{*}\right)$ dan batas bawah $\left(r_{\text {dalam }}^{*}\right)$ yang menjauhi titik pusat $(0,0)$ 
serta sebaran titik-titik inferensi pada $\mathrm{G}_{2}, \mathrm{G}_{3}, \mathrm{G}_{4}$, dan $G_{7}$ menyebar di luar area kontur. Sehingga, genotipe $G_{2}, G_{3}, G_{4}$, dan $G_{7}$ dapat diidentifikasi sebagai genotipe tidak stabil.

Genotipe $\mathrm{G}_{5}$ memiliki daerah kepercayaan batas atas $\left(r_{\text {luar }}^{*}\right)$ dan batas bawah $\left(r_{\text {dalam }}^{*}\right)$ yang mendekati titik pusat $(0,0)$ serta sebaran titik-titik inferensi pada $\mathrm{G}_{5}$ mengumpul dan masih berada di dalam kontur. Sehingga, genotipe $\mathrm{G}_{5}$ dapat diidentifikasi sebagai genotipe stabil.

Genotipe $\mathrm{G}_{6}$ memiliki daerah kepercayaan batas atas $\left(r_{\text {luar }}^{*}\right)$ dan batas bawah $\left(r_{\text {dalam }}^{*}\right)$ yang tidak terpaut jauh dengan titik pusat $(0,0)$ dengan sebaran titik-titik inferensi pada $\mathrm{G}_{6}$ mengumpul pada area lingkaran luar tidak mendekati titik pusat. Sehingga, genotipe $\mathrm{G}_{6}$ dapat diidentifikasi sebagai genotipe tidak stabil.

Dari hasil inferensi titikt-titik amatan dengan metode bootstrap genotipe $\mathrm{G}_{1}$ dan $\mathrm{G}_{5}$ dapat dikatakan sebagai genotipe yang paling stabil, karena sebaran titik-titik $\mathrm{G}_{1}$ dan $\mathrm{G}_{5}$ paling mendekati titik pusat $(0,0)$ dan memiliki jari-jari lingkaran yang kecil.

\section{KESIMPULAN}

Berdasarkan model Mixed AMMI dalam menentukan analisis stabilitas diinterpretasikan melalui biplot $\mathrm{AMMI}_{2}$ antara $\mathrm{KUI}_{1}$ dan $\mathrm{KUI}_{2}$, diperoleh bahwa genotipe yang berada di dalam area kontur dan dekat dengan titik pusat $(0,0)$ dikatakan sebagai genotipe yang stabil. Sebaliknya, genotipe yang berada di luar area kontur dan jauh dari titik pusat $(0,0)$ dikatakan sebagai genotipe yang tidak stabil atau dapat diidentifikasi sebagai genotipe yang hanya mampu stabil di suatu lingkungan tertentu, kemudian untuk genotipe yang berada di sekitar area kontur atau berdekatan dengan kontur belum dapat diidentifikasi secara pasti kestabilan genotipe padi tersebut.

Berdasarkan hasil penelitian diperoleh bahwa metode bootstrap dapat mempertegas stabilitas genotipe padi dari gambaran Biplot $\mathrm{AMMI}_{2}$ pada model Mixed AMMI. Genotipe padi yang diduga stabil, tidak stabil bahkan masih meragukan tingkat kestabilannya pada gambar Biplot $\mathrm{AMMI}_{2}$ dengan metode resampling bootstrap memperlihatkan gambaran inferensi yang diperlukan dalam pendugaan kestabilan genotipe.

\section{DAFTAR PUSTAKA}

[1] Efron, Bradley and Tibshirani, Robert J. 1993. An Introduction to the Bootstrap. New York: Chapman \& Hall.

[2] Jolliffe, I. T. 2002. Principal Component Analysis, $2^{\text {nd }}$ edition. New York: SpingerVerlag.

[3] Lavoranti, O.J., Dias, C.T.S., and Kraznowski, W.J. 2007. Phenotypic Stability Via AMMI Model with Bootstrap Re-sampling. Pesquisa Florestal Bras. http://www.Ice.esalq.usp.br/tadeu/Osmir_T aden_Wotjek.pdf. pp.45-52. Diakses tanggal 10 Maret 2015.

[4] Mattjik, A.A., and Sumertajaya, I.M. 1999. Diktat Analisis Perancangan Percobaan dengan Aplikasi SAS dan MINITAB. Bogor : Institut Pertanian Bogor.

[5] Novianti, Pepi., Mattjik, A.A., and Sumertajaya, I.M. 2010. Pendugaan Kestabilan Genotipe Pada Model AMMI Menggunakan Metode Resampling Bootstrap. Jurnal Forum Statistika dan Komputasi. Vol 15, No 1. Bogor: pp 28-35.

[6] Prihartini, R.R. 2011. "Mixed Additive Main Effect and Multiplicative Interaction (M-AMMI) dan Aplikasinya". Skripsi. Program Studi Matematika Jurusan Pendidikan Matematika Fakultas Matematika dan Ilmu Pengetahuan Alam Universitas Negeri Yogyakarta. Yogyakarta.

[7] Sa'diyah, Halimatus., and Mattjik, A.A. 2011. "Indeks Stabilitas AMMI untuk Penentuan Stabilitas Genotipe pada Percobaan Multilokasi" in Pemodelan Additive Main-effect \& Multiplicative Interaction (AMMI) Kini dan yang Akan Datang. A.A Mattjik, I Made Sumertajaya, Alfian Futuhul Hadi, Gusti Ngurah Adi Wibawa (eds.). Bandung. IPB PRESS: pp 26-34.

[8] Sumertajaya, I.M. 2007. Analisis Statistik Interaksi Genotipe dengan Lingkungan. balitsereal.litbang.pertanian.go.id/eng/leafle t/made.pdf. pp. 1-9. Diakses tanggal 10 Maret 2015. 